\title{
Mądrość jako (z)dewaluowana wartość rozwoju zrównoważonego
}

\author{
Katarzyna kukaszewska \\ Akademia Pedagogiki Specjalnej im. Marii Grzegorzewskiej w Warszawie \\ ul. Szczęśliwicka 40, 02-353 Warszawa \\ klukaszewska@aps.edu.pl•ORCID: 0000-0002-3986-7731
}

\section{Streszczenie}

Celem tekstu jest przypomnienie kategorii mądrości jako podstawowego gwaranta rozwoju. Wartość mądrości rzadko pojawia się we współczesnym dyskursie; rzadko pojawia się w kontekście rozwoju czy to w znaczeniu osobistym, społecznym, czy tym bardziej gospodarczym. Przyzwyczailiśmy się bowiem do operowania językiem korzyści, zysków i efektów. Mądrość zaś nie wydaje się nam przydatna, nie jest rozwojowa, a poza tym wymaga tracenia czasu na myślenie. Tymczasem istnieje przecież, jak twierdzi Hannah Arendt, związek pomiędzy złem a brakiem myślenia. Skoro chcemy równoważyć rozwój tak, by nie zaprzepaszczał szans przyszłych pokoleń, to może warto przypomnieć, że mądrość jest gwarantem dobrego działania w wymiarze woli. To właśnie mądrość determinuje tę wolę.

\section{Słowa kluczowe}

Mądrość, myślenie, poznanie, rozwój zrównoważony, sens, znaczenie, wartość

\section{Rozwój wiedzy niezrównoważonej}

Postulaty rozwoju zrównoważonego bazują na twierdzeniu, że cywilizacja osiągnęła poziom dobrobytu możliwy do utrzymania pod warunkiem dobrego gospodarowania. Proponuję spojrzeć na owo gospodarowanie jako uwarunkowane mądrością, głównie dlatego, że „[...] problemy globalne to przede wszystkim - problemy ludzkie. Jedynie wtórnie można przypisać im przyczyny naturalne" (Bootkin i in. 1982: 48). Owszem, nie jest łatwo przywołać dziś kategorię mądrości na świadka szans harmonijnego rozwoju świata. W zasadzie można by stwierdzić, iż „w nowożytności mądrość została zdegradowana. Nie stanowi pojęcia ważnego teoretycznie, nie jest wyliczana wśród cech, które powinien osiągnąć człowiek" (Borowiecka 1994: 156-166). Zastąpiliśmy mądrość specjalizacją, a sprzężone z mądrością rzemiosło moralne jest praktyką bardzo zapomnianą. Rozwój oznacza dziś tyle, co wzrost gospodarczy, a równoważenie go, szukanie harmonijności, powściągliwości apetytu i rozsądku, nawet jeśli leży na sercu wielu ludziom, to rzadko opiera się na oddolności pracy własnej, jednostkowej, indywidualnej. Zapominamy, że „prawdziwy postęp zaczyna się od tego, czego nie może dać sama wiedza ekonomiczna, czyli od mądrości mówiącej nam, co znaczy żyć dobrze” (Bregman 2018: 24). Nie pamiętamy, że nikt z nas nie żyje w próżni aksjologicznej. To, co określamy mianem klęski w walce z globalnymi zagrożeniami i co czyni nas coraz bardziej zatrwożonymi wobec ignorancji (arogancji?), niekompetencji (niedouczenia?) i bezrefleksyjności (głupoty?), jest tak naprawdę porażką 
w autoedukacji jednostki. W rozwoju społeczeństw, postępie świata i ludzi, „chodzi o działanie poszczególnego człowieka. [...] Millenia, stulecia, czy nawet poszczególne lata nie stają się same, są one tworzone przez ludzi, przez instytucje, przez kultury" (Skolimowski i Górecki 2003: 111-112). Rozwój zrównoważony wcale zrównoważony nie jest i ogromna w tym wina nie tyle braku wiedzy, co braku myślenia. Rozdźwięk między nimi jest ogromny, kuriozalnie odcinając potrzebę refleksyjności od sukcesu, rozwoju i postępu. Właśnie teraz, jak nigdy wcześniej, potrzebujemy planu działania zgodnego z tą kategorią, jej pozorna zaś bezużyteczność opiera się po prostu na czasochłonnym i autoedukacyjnym trudzie scalania tego permanentnego pęknięcia. Nie mam tu na myśli tylko potknięć edukacji jako takiej, raczej rozdźwięk, jaki powstaje dziś notorycznie pomiędzy myśleniem a działaniem, pomiędzy wiedzą a rozumieniem, między kwalifikacjami a kompetencjami. „Bo mądrość nie tylko pozwala poznawać; pozwala «być» inaczej" (Hadot 1992: 222); nie chodzi tylko o zdobycie niezbędnych umiejętności oraz poznania. Chodzi o zmianę w sposobie bycia, życia i postępowania. Na dodatek zazwyczaj rezygnujemy z tego, co trudniej nas do siebie przywiązuje, co wymaga czasu na zrozumienie i pogłębienie relacji; wszak „co nas zakorzenia w życiu? Najsilniej - działanie. Dla wielu osób to ono jest rzeczywiste, normalne, i te wszystkie bzdury filozoficzne, zastanawianie się nad własnym byciem są czczym gadaniem, pustą metafizyką" (Skarga 1999: 245). To pojedynczy człowiek (a wraz z nim całe społeczeństwa) szuka łatwych rozwiązań, tanich i nieabsorbujących zbyt wiele uwagi, marniejąc przy tym, marnotrawiąc czas, więzi, przedmioty, a w końcu i wartości. Natomiast „stechnicyzowany świat, pozbawiony humanistycznych wartości i humanistycznej wiedzy, która wartości te rozwija i pielęgnuje, doprowadzi, co już widać, do zacieśnienia horyzontów, skupienia się na doraźnych wąskich interesach, a dalej do zubożenia języka, uniformizacji gustów na niskim poziomie, standaryzacji wyobraźni itd., itd." (tamże: 128-129). W takiej perspektywie kategoria mądrości pozostaje dla mnie niedocenioną i nieocenionac jednocześnie w perspektywie tak rozwoju, jak i samorozwoju oraz rozwoju zrównoważonego. Potrzebujemy bowiem nie tylko prawdziwych informacji, lecz także zrozumienia ich sensu. Jakkolwiek więc „mądrość jest w istocie stanem, do którego dąży się bez nadziei jego osiągnięcia” (Hadot 1992: 47), to - bez przesadnej chełpliwości w stosunku do osiągalności jakiejś konkretnej postaci owego stanu - ale nie mamy innego wyjścia, jak zmądrzeć. Potrzebujemy sensu bardziej niż poznania, a zwłaszcza myślenia, które umożliwia odszukiwanie znaczenia, nie tylko opis faktów. W perspektywie coraz dotkliwiej rozrastającej się ignorancji wobec ludzi mądrych, rozsądnych, umiarkowanych oraz w nieposzanowaniu dla decyzji przemyślanych, dla trudu budowania wspólnego uniwersum aksjologicznego „wydaje się, że tylko w mądrości odnaleźć można szansę dla naszej kultury" (Skarga 1999: 32.)

\section{Niemyślenie jako zanik znaczeń}

Myślenie to czynność zanikająca, coraz zbędniejsza, problematyzująca rzeczywistość; prowokuje do pytań, a co za tym idzie - zatrzymuje w działaniu, odrywa od wydajności i pracowitości. Dla współczesnego rozumienia rozwoju i postępu wystarczy wiedza, poznawanie, przyzwyczajające do szybkiego gospodarowania informacjami o faktach, nie o ich znaczeniach. Hannah Arendt dostrzegła ten problem, twierdząc, że poznanie, a więc droga do wiedzy, jest szukaniem prawdy (fakty są prawdziwe lub nie). Natomiast myślenie jest szukaniem sensu i należy je „przeciwstawić poznawaniu (zdobywaniu wiedzy). Myślenie zmierza do znaczenia, natomiast poznawanie zmierza do prawdy. [...] Prawdziwe lub nieprawdziwe mogą być tylko fakty, prawda odnosi się jedynie do rzeczy zmysłowo poznawalnych, do rzeczywistości. Kiedy się natomiast myśli, kiedy się filozofuje, zdroworozsądkowe poglądy odnoszące się do rzeczywistości ulegają zawieszeniu" (Arendt 1991: 28). 
Myślenie jest więc swoistym szukaniem znaczeń, dokopywaniem się do tego, co ważne, co ma znaczenie. Dlatego też „myślenie i poznanie nie są tym samym. Myślenie, źródło dzieł sztuki, widoczne jest, nieprzekształcone i nieprzeobrażone, w każdej wielkiej filozofii, podczas gdy głównym przejawem procesów poznawczych, przez które przyswajamy i gromadzimy wiedzę, jest nauka. Poznanie zawsze dąży do określonego celu, którym mogą być zarówno względy praktyczne, jak i «próżna ciekawość»; jednak gdy cel zostaje osiągnięty, proces poznawczy dobiega kresu. Myślenie, przeciwnie, nie ma końca ani celu poza sobą samym i nie wytwarza nawet rezultatów; [...] miłośnicy wyników poznawczych, osiąganych w nauce, często wytykali myśleniu zupełną «bezużyteczność» - rzeczywiście jest ono tak bezużyteczne jak dzieła sztuki, które inspiruje" (Arendt 200o: 188-189). W tym kontekście myślenie rzeczywiście bywa postrzegane jako nieopłacalne, bezproduktywne, jałowe. Nie przynosi ze sobą natychmiastowych efektów poznawczych, a nawet jeśli da się je dostrzec, to i tak pozostają one w sferze znaczeń i sensu, nie zaś prawdy czy fałszu. Chodzi więc również o różnicę nie tylko pomiędzy poznawaniem a myśleniem, lecz także wiedzą a wartościami.

Henryk Elzenberg uważał, że „wartość stwarza sens, nadaje sens; sens płynie z wartości" (Elzenberg 1991: 345). Według Arendt fakty mogą nas jedynie pouczyć o prawdziwym zdarzeniu i dać wiedzę na jakiś temat. Ale to myślenie szuka sensu, chce znaleźć znaczenie, pozwolić człowiekowi być mądrzejszym, otrzeć się o wartość. Zdaniem zaś Barbary Skargi „to przez myślenie otwiera się droga ku mądrości, a mądrość [...] jest wrażliwa na ślady dobra i prowadzi do godnego życia" (Skarga 2001: 143). W praktyce jednak zazwyczaj korzystamy albo z tego, co mówią fakty (i ich prawdziwość), albo z tego, co daje sens, czyli z wartości. Rozbijamy więc strukturę na części: na łatwiejszą do zweryfikowania faktyczność poznania oraz na osobne myślenie szukające znaczeń i sensu, płynących z odkrywania wartości, których znajomość z pewnością nie ułatwia działania w potocznym rozumieniu. Sądzę jednak, że wiedza, która nie myśli, jest gorsza, niż mądrość, która nie wie.

\section{Brak myślenia jako letarg}

Na kategorię mądrości możemy spojrzeć jako na odkrywanie na nowo wiązania, które tak pośpiesznie rozerwaliśmy: istnieje bowiem łączność pomiędzy myśleniem i działaniem, choć wygląda może inaczej, niż byśmy tego chcieli. „Mądre myślenie ma przynieść poczucie sensu i wewnętrznej zgody. Mądre działanie ma być pożyteczne, a więc musi sprzyjać polepszeniu dobrostanu zarówno działającego podmiotu, jak i jego otoczenia. Mądre działanie jest nastawione na tworzenie i powiększanie dobra wspólnego, na powiększanie sumy szczęścia. Rzecz jednak w tym, że mądre działanie nie jest warunkiem koniecznym mądrego myślenia (a w każdym razie nie jest w danym momencie, bo w dłuższej perspektywie być może jest inaczej), natomiast mądre myślenie [...] jest warunkiem koniecznym intencjonalnego mądrego działania" (Łukaszewski 2018: 72). Myślenie w swym zdążaniu do sensu nie jest tylko bezproduktywnością szukania znaczeń, ale ma ogromne wpływ na ponowne scalanie faktów ze znaczeniami i odkrywanie wartości, które sens stwarzają. Samo poznanie wcale nie gwarantuje trafnego rozpoznania sytuacji, znalezienia rozwiązania. Więcej nawet - tak często doświadczana przez nas niepewność i zagubienie są być może właśnie dowodem na destabilizację elementarnego gwaranta bezpieczeństwa, na dodatek mającego podłoże autopsyjne: „Mądrość pozwala na wyselekcjonowanie z ogromnej liczby napływających informacji tych, które są najważniejsze. Ona też umożliwia nam dostrzeżenie pozornej złożoności i nieuporządkowanej rzeczywistości do kwestii najbardziej istotnych. Bez mądrości stajemy bezradni wobec przytłaczającego chaosu informacji, danych, norm i wartości, a z bezradności tej rodzi się bezczynność i apatia. Wypada podkreślić, iż w tym rozumieniu dostępna 
jest ona niezależnie od zawodu i wykształcenia. Ogromną mądrość - właśnie mądrość, a nie wiedzę - można często dostrzec u ludzi prostych i niewykształconych" (Mlicki 1988: 18o-181). Wiedzę możemy pozyskać jako zbiór informacji, ale tylko mądre myślenie będzie potrafiło je selekcjonować, układać, szukać znaczeń i związków. Wiedza nie może zastąpić mądrości; tzn. może, ale - jak twierdzi Arendt - skutkuje to chodzeniem po omacku, nie do końca na jawie i nie w pełni we śnie, na granicy: „myślenie towarzyszy życiu i samo jest niematerialną kwintesencją życia; a skoro życie jest procesem, to jego istota może tkwić tylko w rzeczywistym procesie myślenia, nie zaś w trwałych wynikach lub określonych myślach. Życie bez myślenia jest możliwe; traci jednak wtedy swą własną istotę - jest nie tylko bez znaczenia, jest nie w pełni żywe. Niemyślący ludzie są jak lunatycy" (Arendt 1991: 261).

Ustawiczne nastawienie na wyniki, chroniczność preferowania efektu nad sensem, oduczyło ludzi myślenia. Rezultatem jest postęp bez rozwoju, wiedza bez myślenia, fakty bez wartości i prawdziwość bez sensu, czyli - jak twierdzi Arendt - lunatykowanie. Takie właśnie są skutki zaniku „tego «milczącego dialogu», który od Sokratesa nazywany jest myśleniem. Znamienne są słowa autorki wskazujące na potrzebę powrotu do jedności myślenia i działania jako podstawowych form realizacji człowieczeństwa. Ludzie, którzy nie myślą, w nowych sytuacjach są bezradni”. (Jodłowska 2012: 214). Cóż z tego, że jesteśmy świetnie wykształceni, potrafimy nazwać problem i opisać go ze szczegółami, ale z pełną bezradnością rozkładamy ręce wobec konieczności jego rozwiązania. Sytuacje nowe zawsze będą nas przerażać, ze względu na swe niepoznanie, brak wiedzy o nich. „Mądrość jest produktem ubocznym dążenia czy to do prawdy, czy do systematyzacji myśli i czynów. I często jest produktem jedynym" (Elzenberg 2002: 297). Dlatego brak myślenia ponad pośpiesznością działania i wypunktowaną skrupulatnie wiedzą skutecznie chroni nad przed mądrością.
Lekceważenie myślenia na korzyść skuteczności, efektywności, wymierności, odseparowuje od mądrości także w sensie moralnym. Postępujemy wedle tropów wiedzy, ale nie mądrości, podczas gdy od Sokratesa wiadomo, że nie wystarczy wiedzieć, żeby być mądrym. Rozdźwięk między poziomem wiedzy a brakiem myślenia jest ogromny. „Rozwarcie między wiedzą o tym, co powinno się robić, a tym, co jest, nie tylko się utrzymuje, ale niebezpiecznie się powiększa" (Szmyd 2011: 97). Dla zrównoważonego rozwoju ten pozorny postęp również opiera się o szeroką specjalistyczną wiedzę przy jednoczesnym braku myślenia; jest to uleganie pozorności zrównania wiedzy specjalistycznej z trafną decyzyjnością praktyczną. Zachłystując się certyfikowaniem umiejętności oraz mierzalnością, wymiernością dokonań związanych z poznaniem, zapominamy, że „mądrość nie jest równoznaczna z wiedzą; nie jest budowana tylko w poznaniu teoretycznym lub tylko na drodze doświadczenia praktycznego, lecz wymaga jedności tych procesów; człowiek mądry żyje zgodnie $z$ wymogami prawd, do których doszedł w swoim życiu." (Jodłowska 2012: 131). Prawda i sens muszą się spotkać w mądrości. To, co wiem, musi w jakiś sposób organizować moje decyzje, wpływać na postępowanie, jeśli natomiast jest to tylko martwy zbiór informacji, poznanie nie uaktywnia mnie zupełnie. Jestem bezradny w decyzji, nie umiem jej podjąć, mogę co najwyżej rozpatrzyć ewentualne możliwości. Na poziomie jednostkowym działanie i myślenie są tak odległe od siebie, ze trudno oczekiwać jedności w sprawnym postepowaniu. A szkoda, przecież myślenie uniezależnia; pozwala na życie bez mgły; chociaż jednocześnie mądrość, proponowana w zamian za myślową niesamodzielność, oznacza bardzo trudne bycie. Czemu więc mielibyśmy decydować się na ten trud? Dlatego, że „istnieje bowiem - jak twierdzi Arendt - niezaprzeczalny związek pomiędzy złem a «brakiem myślenia»" (tamże: 29). Nie tylko jesteśmy zdolni zapobiegać takiemu złu, lecz także jesteśmy wręcz do niego zobligowani; nie 
ma zbyt wiele czasu, żeby próbować odkładać myślenie na później, za bardzo przegrywamy w walce z globalnymi zagrożeniami. Dziś „każdy jest zobowiązany do współmyślenia" (Picht 1981: 57), jakkolwiek ryzykownie optymistyczny jest to warunek. Bez tego trudno będzie jednak w rozwoju odnaleźć jakiekolwiek zrównoważenie. Po prostu „nadszedł czas na powrót do utopijnego myślenia” (Bregman 2018: 25).

\section{Mądrość angażująca wolę, czyli myślenie a wybór dobra}

Bez myślenia rozwój jest niemożliwy, jakie myślenie - takie działanie. Dlatego rozwój zrównoważony zaczyna się od postaw i zachowań indywidualnego człowieka, nie odgórnie. „[...] problemy globalne to przede wszystkim - problemy ludzkie. Jedynie wtórnie można przypisać im przyczyny naturalne" (Bootkin in. 1982: 48) i dlatego żadna dyrektywa nie wprowadzi stosownych zmian; nic nie zdeterminuje woli do tego stopnia, by naprawdę zacząć gospodarować rozważnie, myśleć o sensie tego, co się robi tylko mądrość to potrafi: sprawiać, że działanie ma znaczenie, a myślenie sens. „To, co jest, powinno zostać zapośredniczone przez myślenie, którego poziom wzrasta wraz z wychowaniem rozumności w człowieku" (Jodłowska 2012: 142). Można przecież przyswoić sobie mnóstwo informacji w sposób nieuświadomiony, natomiast myśleć nie da się bez świadomości. Ponadto „okazuje się, że aby postępować moralnie, trzeba mieć świadomość niewiedzy. Obyczajność naiwna musi być zastąpiona świadomą. Naturalne życie oparte na obyczaju nie wystarcza, aby być moralnym” (tamże: 142). Myślenie nie jest mimowolne; dlatego „Sokrates uczy także, że mądrość ma również swój aspekt moralny. Możliwość poznania dobra zobowiązuje do postępowania według tej wiedzy. W ten sposób mądrość łączy się z innymi przymiotami charakteru, takimi jak: sprawiedliwość, rozwaga, prawość, pokora wobec świata, uwielbienie nieoczywistości i adogmatyczności w myśleniu, umiłowanie prawdy, myślenie uwzględniające wiele perspektyw, wnikliwe, wątpiące, refleksyjne" (tamże: 131-132). Myślenie oddala niebezpieczeństwo kumulacji wyłącznie samej wiedzy. Słynna sokratejska świadomość własnej niewiedzy jest mądrzejszym wsparciem dla woli niż nieświadomość wiedzy; cóż z tego, że posiadamy określony zasób informacji, jeśli są one dla nas niezrozumiałe, nieprzyswojone, całkiem eksterytorialne; to, co wiem, może skutecznie usypiać w poczuciu wystarczalności własnych informacji, hamując rozwój; świadomość niewystarczalności własnej wiedzy skutecznie pobudza do działania, co prawda z dużo większą ostrożnością, ale za to w obecności świadomości. Bezmyślność, brak świadomości psuje wolę, stępia ją, zastępuje świadomy wybór analizą faktów, kumulacją opcji i możliwości, z którego to nagromadzenia nic nie wynika. Wiedza nie musi wpływać na decyzyjność, myślenie zaś do niech przynagla. W tym sensie niepodobnym jest wiedzieć i nie zrobić zgodnie z tą wiedzą. Etyczny intelektualizm wcale nie jest naiwny - nie wystarcza bowiem wiedzieć, co jest dobre, trzeba jeszcze tego chcieć. Sokratesowi, jako wzorowemu miłośnikowi mądrości, zależało „na przekonaniu wszystkich do swojej tezy, że nie ma tak naprawdę miejsca na odróżnianie poznania (wiedzy) od działania, ponieważ kto poznał dobro, tym samym rozumie, że należy czynić podług tej wiedzy; ten będzie przejawiał pragnienie dobra i wykazywał wolę, by dobro realizować w życiu" (tamże: 145). To, co odróżnia świadomość, że się nie wie, od nieświadomości, że się wie - to właśnie myślenie, podstawa mądrości. Mądrość angażuje i świadomość, i wolę, stając się zamierzonym praktykowaniem wyborów przemyślanych. Tak pojęta mądrość odsuwa obawę Hannah Arendt o chroniczny rozpad na osobność: albo wiedza, albo działanie. Wiedza wszak nie musi zakorzeniać się w wyborach człowieka - mądrość tak. Nie chodzi tylko o to, żeby wybierać to, co dobre, ale by chcieć tego, co dobre i jednocześnie to wybierać. Dobry wybór wcale nie oznacza, że jestem do tego wyboru wewnętrznie przekonany. Wiedza nie wystarcza do mądrości, nie jest cnotą, 
potrzeba jeszcze uświadomienia sobie, czym tak naprawdę jest wiedza, którą rozumiem. Jeśli nie rozumiem, mechanicznie powtarzane i przetwarzane informacje, jakkolwiek mnogie, nie zrobią ze mnie człowieka mądrego. Wola, która chce wiedzy rozumnej, nie poprzestaje na informacji, ale chce umiejętności praktycznych, które ta wiedza daje. Chcieć tego, co dobre, staje się sednem rozwoju, w tym kontekście także samorozwoju. „Można powiedzieć, że mądrość warunkuje wolę, ale i ona sama buduje się na tej wielkiej sile rządzącej ludzkim życiem. Sokrates wiedział, że refleksja nad ludzką «wolą» jest kluczem do mądrości" (tamże: 16). Tymczasem niemyślenie jest wstępem do głupoty, czyli chronicznej bezrefleksyjności, permanentnego niemyślenia. Każdemu z nas zdarza się postąpić czasem bezmyślnie, pobieżnie myślowo, pospiesznie i bez zastanowienia. Chroniczna jednak bezmyślność, jako brak myślenia, zyskuje walor moralny i w tym sensie jest zła, krzywdząca, pozbawiająca sensu; powierzchowna jak wiedza, która nie wpływa na decyzyjność w żaden sposób, ani nie utrwala wyboru.

\section{Mądrość - powrót do myślenia w działaniu}

Próbując zrozumieć, czym jest mądrość, trzeba samemu stawać się mądrzejszym. Dlatego uważam, że żeby chcieć rozwoju zrównoważonego, trzeba najpierw rozumieć, czym jest rozwój w wymiarze indywidualnym. „Dzisiaj uznajemy, że rozwój to termin ekonomiczny i techniczny. Dawniej odnosił się jednak do sfery duchowej i wewnętrznej" (Sedláček 2012: 244), dziś kojarzy nam się głównie, jeśli nie wyłącznie, z rozwojem gospodarczym. Wydaje mi się, że to konsekwencja podejścia znanego już od pierwszych sofistów: „Protagoras uczył zaradności (eubulia)" (Jodłowska 2012: 56). Współczesny wymiar owego „radzenia sobie" bardzo dobrze znamy; całe społeczeństwa oczekują poznania recepty na sukces życiowy oparty na zaradności, pomysłowości i przedsiębiorczości, w połączeniu z finansowym progresem. Tymczasem ktoś, kto radzi sobie, czy też radzi innym, wcale nie oznacza, że potrafi myśleć. A tylko taka umiejętność pozwala ze spokojem patrzeć na rozwój zdroworozsądkowej więzi między wiedzą a działaniem. Jeżeli różnicuję wiedzę i mądrość, to dlatego, iż mamy już zdecydowanie za dużo specjalistów, profesjonalistów pozbawionych sprawczości, tak jak i tyleż popularnego, co stale podupadającego moralnie „radzenia sobie”. Mądrość jako kategoria postępu jest konieczna. Zdolności umożliwiające myślenie wspólnymi kategoriami, usensawiającymi poznanie wartościami, pozwalające widzieć rozwój z uwzględnieniem równowagi i harmonii - posiadają wyłącznie ludzie mądrzy. Nie chodzi o negację wiedzy i poznania, o deprecjację racjonalności i szukania prawdziwości, a jedynie o przypomnienie, że rozbicie obu form racjonalności - poznawania i myślenia, prawdy i sensu - powoduje, że jakikolwiek rozwój, w tym zwłaszcza zrównoważony, zostaje pozbawiony stabilnej płaszczyzny, swego fundamentu celowego poznawania świata. „Można zatem powiedzieć, że racjonalnie jest dążyć do racjonalności, ale głównie poprzez tworzenie warunków, w których może ona «zafunkcjonować» pozytywnie dla globalnych interesów ludzkości i świata" (Zacher i Świątkowski 1995: 12). Dziś mało kto chce te warunki tworzyć, raczej chodzi o zbieranie efektywności i produktywności, a nie umożliwianie wprowadzania zmian oddolnie. Miejmy nadzieję, że „ludzie wyznaczający drogi w kierunku trwałego i zrównoważonego rozwoju świata zrozumieli, że nic nie dadzą działania rządów, organizacji międzynarodowych, wspaniale opracowane dokumenty, jeżeli nie włączymy w tę działalność społeczeństw, z naciskiem na rozwój indywidualnego człowieka" (Stachowska-Makuchowska 2013: 27). Dlatego właśnie staram się odnosić zagadnienia związane ze zrównoważonym rozwojem do rozwoju jako takiego, a co za tym idzie do rozwoju indywidualnego człowieka, do jego osobistej refleksyjności, zdolności do trwałego myślenia sprzężonego z wolą. Bezmyślność skutkuje bezradnością, wiedza 
bez przekonania - bezwolnością, tylko zaś mądrość zdaje się jednoczyć na powrót myślenie z działaniem, zasypując ogromną przepaść między racjonalnym poznaniem a sprawczością.

Mądrość nie jest anachronizmem przeczącym postępowi, natomiast „to hołubienie naszych potrzeb [...] jest zaprzeczeniem mądrości” (Schumacher 1981: 45). Promocja zmiany jako takiej i rozbudowywania kolejnych szczebli postępu jest chronicznym polepszaniem sytuacji, szukaniem możności raczej niż potrzebności. Równowaga własnych potrzeb często postrzegana jest jako wykluczająca z postępu - trudno jest nam często zrozumieć, że można czegoś nie mieć i jednocześnie tego nie chcieć i to nie z powodu braku środków finansowych. A przecież „życie ekologiczne nie musi oznaczać odwrócenia się od postępu gospodarczego; chodzi raczej o to, by odkryć, które technologie są bardziej przydatne z punktu widzenia zrównoważonej przyszłości. Ekologiczny styl życia nie jest ścieżką «bez wzrostu», ale ścieżką «innego wzrostu» - takiego, który uwzględnia zarówno materialny, jak i duchowy wymiar życia. Prostszy sposób życia nie neguje postępu" (Elgin 2004: 282). Innym, odmiennym sposobem rozwoju jest też szukanie mądrych rozwiązań a nie wyłącznie unowocześnionych, pozwalających prężnie działać, wciąż ulepszać, stale zmieniać. Zwłaszcza, że „z punktu widzenia ekonomii podstawową koncepcją mądrości jest trwałość" (Schumacher 1981: 45). Mądrość jest więc w stanie generować to, co trwałe, stanowiąc koncept długoterminowy. Rozwój oparty na samej wiedzy, na samym tylko działaniu, bez myślenia - tworzy zmianę rozumianą wyłącznie jako wzrost, polepszanie, udoskonalanie, które nie muszą posiadać koniecznie przesłanki celowej, wystarczy jej sam ruch. Tymczasem nie każdy krok w przód jest rozwojem. Potrafimy przedstawić setki analiz prognozujących wzrost i rozwój, których nie można odnieść do znaczenia, do sensu, bo nie mają związku z jakąkolwiek realną zmianą w świecie, którą można by utrwalić. Dzieje się tak coraz częściej, ponieważ „jedność myślenia i działania została rozerwana, jednostkom pozostały dwa uczciwe wyjścia - poświęcić się tylko myśleniu lub tylko działaniu. [...]. Między takim myśleniem a działaniem nie ma już żadnego związku. To znaczy: potrafimy bardzo precyzyjnie przedstawić argumenty za tym, że warto pójść do kina, i za tym, że warto zostać w domu, jednak odmawiamy odpowiedzi na pytanie, czy lepiej iść do kina, czy zostać w domu [....] Myślenie więc działaniu, które polega na nieustannym przecież dokonywaniu wyborów, podejmowaniu nieodwracalnych decyzji, przestało służyć" (Król 1991: 10). Nic dziwnego, że wiedza przestała też służyć rozwojowi. Samo poznanie - nie zmienia działania. To nie prawda, że nie stać nas na myślenie, bo potrzebujemy konkretnego działania i to szybko, zwłaszcza w wymiarze rozwoju zrównoważonego. Jest dokładnie odwrotnie - nie możemy już dłużej pozwolić sobie na marnotrawienie mądrego myślenia. Należy bowiem pamiętać, że „istnieje jednak pewien rodzaj marnotrawstwa mający jeszcze większy wpływ na cały splot problemów globalnych [...] niż trwonienie zasobów fizycznych. Chodzi tu o trwonienie ludzkiego potencjału w dziedzinie uczenia się. [...] Lekceważenie zdolności umysłu ludzkiego prowadzi w najgorszym przypadku do kontynuacji cyklu ignorancji i nędzy" (Botkin i in. 1982: 151). Bagatelizowanie mądrości skupia nas na technice, samym procesie wiedzy bez związków, jakie tworzy. Zgadzam się, że „wyobraźnia stanowi nieodłączny element odpowiedzialności" (Helena Ciążela 2006: 59). Uważam, że mądrość - rozwój zrównoważony pozostaje w orbicie strachu przed głupotą bardziej nawet niż przed brakiem wyobraźni. I chociaż „być może nie uzyska się mądrości, o jakiej marzymy, ale nie oznacza to, że nie warto, a nawet, że nie należy stawiać sobie takich ambitnych, choć przecież dalekich celów i dążyć do ich realizacji. [...] ma to ogromne znaczenie, nawet w tak trudnych czasach jak obecne, a może szczególnie w takich czasach powrót do mądrości [...] jest nie tylko wskazany, ale wręcz 
konieczny" (Jodłowska 2012: 12). Przecież mądrość to nie jest tylko marzenie filozofów, to praktyka refleksyjnego pojmowania świata - bez niej nie ma rozwoju.

\section{Bibliografia}

Szkołut T. (red.), 1994, Aksjologiczne dylematy epoki wspótczesnej, Lublin, Wydawnictwo UMCS.

Arendt H., 20oo, Kondycja ludzka, Warszawa, Fundacja Aletheia.

Arendt H., 1991, Myślenie, Warszawa, Czytelnik.

Bootkin J.W., Elmandjra M., Malitza M., 1982, Uczyć sie - bez granic. Jak zewrzeć „lukę ludzka”? Warszawa, PWN.

Bregman R., 2018, Utopia dla realistów, Warszawa, Czarna Owca.

Ciążela H., 2006, Problemy i dylematy etyki odpowiedzialności globalnej, Warszawa, Wydawnictwo APS.

Duane E., 2004, Dobrowolna prostota życia, w: Budiner A.H. (red.), Uważność na targowisku. Globalny rynek $i$ masowa konsumpcja a świadome życie, Warszawa, Wydawnictwo Jacek Santorski \& Co.

Elzenberg H., 2002, Ktopot z istnieniem. Aforyzmy w porzadku czasu, Toruń, Wydawnictwo UMK.

Elzenberg H., 1991, Z filozofii kultury, Kraków, Znak.

Hadot P., 1992, Filozofia jako ćwiczenie duchowe, Warszawa, Wydawnictwo Instytutu Filozofii i Socjologii PAN.

Jodłowska B., 2012, Pedagogika sokratejska, Kraków, Wydawnictwo Impuls.

Król M., 1991, Wstęp, w: Arendt H. (red.), Myślenie, Warszawa, Czytelnik.

Łukaszewski W., 2018, Mądrość i inne niemadrości, Sopot, Smak Słowa.
Mlicki M.K., 1988, Świadome człowieczeństwo, Warszawa, Nasza Księgarnia.

Picht G., 1981, Odwaga utopii, Warszawa, Państwowy Instytut Wydawniczy.

Schumacher E.F., 1981, Małe jest piękne. Spojrzenie na gospodarké świata $z$ założeniem, że człowiek coś znaczy, Warszawa, Państwowy Instytut Wydawniczy.

Sedláček T., 2012, Ekonomia dobra i zła, Warszawa, Wydawnictwo Studio Emka.

Skarga B., 2001, Człowiek agatologiczny, w: Zuziak W. (red.), Pytajac o człowieka - myśl filozoficzna Józefa Tischnera, Kraków, Znak.

Skarga B., 1999, O filozofię bać się nie musimy. Szkice z rożnych lat, Warszawa, Wydawnictwo Naukowe PWN.

Skolimowski H., Górecki J. K., 2003, Zielone oko kosmosu. Wokót filozofii w rozmowie i esejach, Wrocław, Alta 2.

Stachowska-Makuchowska M., 2013, Podstawowe założenia zrównoważonego rozwoju, w: Szadzińska E. (red.), Dydaktyczne „tropy” zrównoważonego rozwoju w edukacji, Kraków, Impuls.

Szmyd J., 2011, Odczytywanie wspótczesności. Perspektywa antropologiczna, etyczna i edukacyjna, Kraków, Krakowskie Wydawnictwo Edukacyjne - Oficyna Wydawnicza AFM.

Zacher L.W., Świątkowski M., 1995, Środowisko człowieka jako wartość uniwersalna i globalna, w: Dębowski J. (red.), Człowiek i środowisko, prace I Olsztyńskiego Sympozjum ekologicznego, Olsztyn 5-6 maja 1994, Studia i Materiały WSP w Olsztynie, Olsztyn.

\title{
Wisdom as a devalued value of sustainable development
}

\begin{abstract}
In this article, wisdom is presented as an elementary guarantor of development. The value of wisdom is not often treated as a part of development in any of personal, social or economic way. More common is the language of benefits, profits and effects. Wisdom is not treated as very helpful in development because it requires too much time spent thinking. However, as we can learn from Hannah Arendt, there is a connection between evil and the absence of thinking. If sustainable development matters to us, we must remember that wisdom determines our will and choice to do right.
\end{abstract}

\section{Keywords}

wisdom, thinking, sustainable development, sense, value 